\title{
The Relationship between Learner Autonomy and Vocabulary Learning Strategies in Iranian EFL Learners with Different Language Proficiency Level
}

\author{
Ebrahim Azimi Mohammad Abadi (M.A.) (Corresponding Author) \\ College of Foreign Languages and Literature, Science and Research Branch, IAU, Tehran, Iran \\ E-mail: e.azimi86@gmail.com \\ Abdollah Baradaran (Ph.D.) \\ Foreign Language Faculty, Central Tehran Branch, IAU, Tehran, Iran \\ E-mail: baradaranabdollah@yahoo.com
}

Received: 06-02-2013

doi:10.7575/aiac.ijalel.v.2n.3p.176
Accepted: 28-03-2013

Published: 01-05-2013

URL: http://dx.doi.org/10.7575/aiac.ijalel.v.2n.3p.176

\begin{abstract}
Vocabulary learning is incredibly noteworthy to English language acquisition. It is unfeasible for a learner to communicate without the required vocabulary. In high education levels, learners are habitually forced to become autonomous and make conscious effort to learn vocabulary outside of the classroom. Consequently, the autonomy of the learners plays an important role in developing and enhancing their vocabulary. Learner autonomy is a huge assistance for learners in vocabulary learning since it provides the learners with numerous diverse privileges such as independency from teacher. The researcher investigated whether there is any statistically significant relationship between learner autonomy and vocabulary learning strategies use in Iranian EFL learners with different language proficiency levels. To meet the above purpose, a total number of 190 male and female EFL learners participated in this study. The methodology underlying this study was quantitative (thorough the administration of two questionnaires and two language proficiency test - TOEFL for advanced group, and Nelson for intermediate level). The quantitative data was analyzed using a set of correlational analysis revealing a significant positive correlation between learner autonomy and vocabulary learning strategies use in high proficient group, and a significant positive relationship between these two constructs in low proficient group, however not as strong as in the advanced group.
\end{abstract}

Keywords: Learner Autonomy, Vocabulary Learning Strategies, EFL Learner

\section{Introduction}

The inspiration of learner autonomy is by no means a fresh building block in the history of education. Learner autonomy, as a new field of study, has slowly come into existence since the 1970s as an outcome of a new move in interest in studies on language learning: learners have gradually been viewed as producers of language and less as learners of a system imposed on them by society (Bocanegra \& Haidi, 1999).

Learner autonomy, according to Dafei (2007), is one of the most vital issues that decide whether an individual reaches his/her potential or falls short of that potential.

Little (1995) believed that autonomous learners comprehend the rationale of their learning agenda, overtly accept responsibility for their learning, split in the setting of learning objectives, take initiatives in planning and doing learning activities, and frequently review their learning and assess its effectiveness.

Cotteral (2000) stated that many language teachers have recognized the importance of taking into account the principles of learner autonomy--the capability to take charge and control one's own learning. He proposes that teachers can encourage students to undertake independent learning outside the classroom.

It is impracticable for a learner to exchange a few words without the desirable vocabulary. No hesitation that a learner cannot learn all language vocabulary in classes so he is supposed to find other ways to learn vocabulary. Learner autonomy is an immense relief for learners in vocabulary learning because it provides the learners with many privileges (Gu \& Johnson, 1996).

The precedent decade has seen a substantial growth of interest in vocabulary studies, mainly in the context of linguistics applied to second language learning and teaching (Carter, 1987; Carter \& McCarthy, 1988; Gairns \& Redman, 1986, cited in Carter, 1989).

Learning strategies are the mindful thoughts and actions that learners apply in order to attain a learning goal. Strategic learners have metacognitive awareness about their own thinking and learning approaches, a high-quality comprehension of what a task involves, and the ability to coordinate the strategies that best meet both the task demands and their own learning strengths (Chamot, 2004). 
Language learning styles and strategies are in the midst of the core features that assist determine how -and how well our students learn a second or foreign language, Oxford (2003).

Generally, learner autonomy in vocabulary learning is desired in any education. Students enter the language courses with diverse backgrounds and learning accomplishments, but, unfortunately, they have a small number of autonomous dispositions which advanced education necessitates in learning. They lack the knowledge of how to achieve by themselves, which requires some supervision and assistance from their teachers and tutors. So enhancing learner autonomy in vocabulary learning is a must for the great impact that it causes on learning process. Therefore, the researcher tried to investigate whether there is a statistically meaningful relationship between learner autonomy (LA) and vocabulary learning strategies (VLS) in Iranian EFL learners with different language proficiency levels.

With regard to afro-mentioned points, the following null-hypotheses were stated:

H0 (1): there is no relationship between learner autonomy and vocabulary learning strategies in Iranian advanced EFL learners.

H0 (2): Learner autonomy does not significantly predict vocabulary learning strategies in Iranian advanced EFL learners.

H0 (3): there is no relationship between learner autonomy and vocabulary learning strategies in intermediate Iranian EFL learners.

H0 (4): Learner autonomy does not significantly predict vocabulary learning strategies in Iranian intermediate EFL learners.

\section{Review of the related literature}

\subsection{Learner Autonomy}

In about twenty years after the Second World War, autonomy, self-direction, and self-access that all refer to the same concept entered into the field of education and went under analyses and researches, and as the time passed, it became more and more familiar in the field of education (Gremmo \& Riley, 1995). Since 1980s, autonomy in language learning has been a subject of prevalent debate.

According to Littlewood (1999), definitions of autonomy have varied, but they have typically included these vital features:

- Students should take responsibility for their own learning.

- Taking responsibility' involves learners in taking ownership (partial or total) of many processes which have traditionally belonged to the teacher, such as deciding on learning objectives, selecting learning methods and evaluating progress.

Little (2007, p.26) defines learner autonomy as "Learner autonomy is the product of an interactive process in which the teacher gradually enlarges the scope of her learners' autonomy by gradually allowing them to take more control of the process and content of their learning".

Littlewood (1996) believed that the influencing goal of teaching is to produce learners that can act and think more independently, i.e. more autonomously, and a strategy for developing autonomy is the main target of language teaching.

As Scharle and Szabo (2000) pointed out, we do not consider of conscientious learners as role models (or teacher's pets), but as learners who admit the idea that their own endeavor are significant to develop in learning, and behave accordingly. Consequently, when doing their homework or answering a question in class, they are not trying to satisfy the tutor, or to get a good mark. They are basically making an attempt in order to learn something

\subsection{Vocabulary Learning Strategies}

Learning strategies are the cognizant beliefs and actions that learners apply in order to get a learning objective. Strategic learners have metacognitive knowledge about their own thinking and learning approaches, a good comprehension of what a task requires, and the ability to match the strategies that best meet both the task demands and their own learning strengths (Chamot, 2004).Vocabulary Learning Strategies can be viewed as a division of general learning strategies in second language acquisition. Vocabulary is vital to language and of serious significance to the normal language learner. Lack of vocabulary knowledge will lead in lack of meaningful communication. The chief advantage that can be attained from all learning strategies is autonomy; students can take charge of their own learning and expand independence and self-direction.

Nation (2001) believes that an outsized amount of vocabulary can be achieved with the asses of vocabulary learning strategies and that the strategies confirm useful for students of diverse language levels.

\subsubsection{Factors Affecting Vocabulary Learning Strategies}

Countless factors appear to play a role in vocabulary expansion, though the precise nature of the role is not always overtly understood. A number of factors are to do with input, in other words the way in which vocabulary presents itself to learners, for example through teacher presentation, reading words in texts, learning words during peer exchange, or through self-access work of some kind. Other factors are to do with storing, organizing, and building vocabulary in the mental lexicon and being able to retrieve or recall it when it is needed (Hedge, 2000).

Oxford (1994) believes that the following factors influence the choice of strategies used among students learning a second language. 
- Motivation

- Gender

- Cultural background Attitudes and beliefs

- Type of task

- Age and 12 stag

- Learning style

- Tolerance of ambiguity

For instance, learning style (general approach to language learning) often determined the choice of L2 learning strategies. For example, analytic-style students preferred strategies such as contrastive analysis, rule-learning, and dissecting words and phrases, while global students used strategies to find meaning (guessing, scanning, predicting) and to converse without knowing all the words (paraphrasing, gesturing).

\subsection{Autonomy and Vocabulary Learning}

Autonomous learners take control and responsibility for their own learning. Nation (2001) believed the point that this does not necessarily mean that they study alone. It is possible to be an autonomous learner in a strongly teacher-led class, by deciding what should be given the greatest attention and effort, what should be looked at again later, how the material presented should be mentally processed, and how interaction with the teacher and others in the class should be carried out.

\section{Method}

\subsection{Participants}

The population of the study consisted of 190 male and female learners (95 learners studying English in the advanced levels and 95 ones in the intermediate level). After the administrations of two language proficiency tests, those whose scores were within the range of one standard deviation above the mean and one standard deviation below the mean were selected and also classified as high/low proficient for the study. It should be noted here that all the participants were above 20 years old; in addition, for two groups to be the same in the number of the learners, a couple of learners who were within the score range were randomly omitted.

\subsection{Instruments}

A couple of questionnaires and two language proficiency tests were utilized in this study. Language learning strategies are recognized through self-report. Even though self-report may be imprecise if the learner does not report honestly, it is still the single way to discover learners' mental processing; Learning strategies are for the most part unobservable, though some may be linked with an observable performance. For instance, a learner could use selective attention (unobservable) to concentrate on the chief ideas while listening to a newscast and could then decide to take notes (observable) in order to recall the information. In almost all learning contexts, the only way to figure out whether learners are utilizing learning strategies while occupied in a language task is to ask them (Chamot, 2004).

\subsubsection{Language Proficiency Tests}

In order to divide the participants into advanced/intermediate learners, the researcher used two language proficiency tests --a TOEFL test for advanced students, and a NELSON test for intermediate ones. Before administrating the tests to the main groups, the tests were piloted in order to have the essential modifications.

Tables 3.1 and 3.2 show the reliability of TOEFL test and Nelson test.

Table 3.1 Reliability Statistics of TOEFL

\begin{tabular}{cc}
\hline Cronbach's Alpha & N of items \\
\hline .763 & 90 \\
\hline
\end{tabular}

Table 3.2 reliability statistics of Nelson

\begin{tabular}{cc}
\hline Cronbach's Alpha & N of items \\
\hline .803 & 50 \\
\hline
\end{tabular}

\subsubsection{Learner Autonomy Questionnaire}

The learner autonomy construct was operationalzed through scores obtained from a learner autonomy questionnaire. The questionnaire was designed by Zhang and Li (2004, cited in Dafei, 2007), and also used by Haghi (2009), which include 21 items (5-point Likert-scale questionnaire). An example "I think I have the ability to learn English well." Followed by 5 letters, the learner autonomy scale has an A point (corresponding to never or total lack of occurrence of that behavior)B, C, D, E (corresponding to always), options were valued from 1 to 5, i.e. option A equaled 1 and option E equaled 5.

\subsubsection{Vocabulary Learning Strategies Questionnaire (VLSQ)}

The researcher utilized a vocabulary learning strategies questionnaire to determine students' self-reported vocabulary learning strategy use. The questionnaire was used by Gu and Johnson (1996) and Tahmasebi (1999). The questionnaire 
includes vocabulary-learning strategies. It contains 91 statements. Vocabulary learning strategy use is divided into seven major parts: metacognitive strategies, dictionary strategies, guessing strategies, note-taking strategies, memory strategies: rehearsal, memory strategies: encoding, and activation strategies. The respondents were asked to rate each statement on a five-point scale based on the frequency of use, ranging from almost never (1) to almost always (5).

\subsection{Procedure}

The investigation consisted of two phases: first, before administrating the Language Proficiency Tests to the main groups, the tests were piloted in order to have essential modifications. Having done the necessary revisions, the proficiency tests were administrated to the participants (TOEFL test for learners in the advanced level and Nelson test for learners in the intermediate level) and a total number of male and female learners whose scores were within the range of on score above the mean and one score below the mean were selected and classified as advanced/intermediate learners for the study. It should be also stated that for two groups to be the identical in the number of the learners, a couple of learners who were within the score range were randomly omitted.

Having homogenized the participants and put them into advanced and intermediate groups, the Learner Autonomy Questionnaire (LAQ) and the Vocabulary Learning Strategies Questionnaire (VLSQ) were given to the participants. The researcher allocated certain amount of time and set a same place in order to have an almost same setting for the all participants so as to minimize affecting factors in participants' performance. The participants were also told that their identities in the study would be anonymous. The participants were asked to answer the questionnaire truthfully.

\section{Results and Discussion}

It should be noted that the present study is descriptive as well as correlational one. In second language acquisition, Mackey and Gass (2005) argue that descriptive research provides description on naturally occurring phenomena connected with language development and processing. Correlational research, on the other hand, determines whether a relationship exists between variables and, if so, the strength of that relationship. This is often tested statistically through correlations, which allows a researcher to determine how closely two variables (e.g. motivation and language ability) are related in a given population.

The present study is descriptive since it aims to determine the frequency and range of autonomy and L2 vocabulary learning strategies of the Iranian EFL learners with different language proficiency level and correlational since it aims to find meaningful relationship between the variables under study, that is, learner autonomy and L2 vocabulary learning strategies in Iranian EFL learners.

\subsection{Descriptive Statistics of Learner Autonomy in the Advanced Level}

One of the instruments used in this study was the learner Autonomy Questionnaire. The descriptive statistics of the questionnaire with participants in advanced level is given in table 4.1.

Table 4.1 Descriptive Statistics of Learner Autonomy in Advanced Level

\begin{tabular}{llllll}
\hline & $\mathrm{N}$ & Minimum & $\begin{array}{l}\text { Maximu } \\
\mathrm{m}\end{array}$ & Mean & $\begin{array}{l}\text { Std. } \\
\text { Deviation }\end{array}$ \\
\hline Learner Autonomy & 95 & 61.00 & 90.00 & 78.1895 & 8.35807 \\
\hline
\end{tabular}

As it is shown above, the maximum and minimum scores obtained by the participants were 90 and 61 , respectively. The mean was 78.18 , and the standard deviation was 8.35 .

\subsection{Descriptive Statistics of Learner Autonomy in the Intermediate Level}

The descriptive statistics of Learner Autonomy in intermediate level is shown in table 4.2.

Table 4.2 Descriptive statistics of Learner Autonomy in Intermediate Level

\begin{tabular}{cccccc}
\hline & $\mathrm{N}$ & $\begin{array}{c}\text { Minimu } \\
\mathrm{m}\end{array}$ & $\begin{array}{c}\text { Maximu } \\
\mathrm{m}\end{array}$ & Mean & $\begin{array}{c}\text { Std. } \\
\text { Deviation }\end{array}$ \\
\hline Learner autonomy & 95 & 44.00 & 80.00 & 61.1684 & 10.49179 \\
\hline
\end{tabular}

According to Table 4.2, the mean of this questionnaire was 61.16, and the standard deviation was 10.49 . The maximum and the minimum scores obtained by the participants were 80 and 44, respectively.

\subsection{Descriptive Statistics of VLS in the Advanced Level}

The descriptive statistics of VLS in advanced participants is presented in table 4.3. 
Table 4.3 Descriptive statistics of VLS in advanced group

\begin{tabular}{llcccc}
\hline & $\mathrm{N}$ & Minimum & Maximum & Mean & $\begin{array}{c}\text { Std. } \\
\text { Deviation }\end{array}$ \\
\hline Metacognitive Regulation & 95 & 15.00 & 58.00 & 46.5895 & 6.18422 \\
\hline Guessing Strategies & 95 & 19.00 & 59.00 & 45.5053 & 7.44751 \\
\hline Dictionary Strategies & 95 & 24.00 & 85.00 & 69.1474 & 9.10456 \\
\hline Note-Taking Strategies & 95 & 11.00 & 45.00 & 32.8421 & 8.21560 \\
\hline $\begin{array}{l}\text { Memory-Strategies: } \\
\text { Rehearsal }\end{array}$ & 95 & 16.00 & 60.00 & 36.8526 & 12.36155 \\
\hline $\begin{array}{l}\text { Memory-strategies: } \\
\text { Encoding }\end{array}$ & 95 & 41.00 & 104.00 & 75.7684 & 21.59760 \\
\hline Activation Strategies & 95 & 7.00 & 25.00 & 17.8421 & 5.50303 \\
\hline Valid N (listwise) & 95 & & & & \\
& & & & &
\end{tabular}

According to the above results, memory-strategies: encoding enjoys the highest mean (75.76) indicating the point that they are the most favorable strategies used by the students in the advanced level. Dictionary Strategies stand on the second rank and Metacognitive Strategies and Guessing Strategies are the followings ranks; and the least favorite strategies are Activation Strategies with the mean of 17.84. Figure 4.1 shows the related histogram of VLS in advanced group.

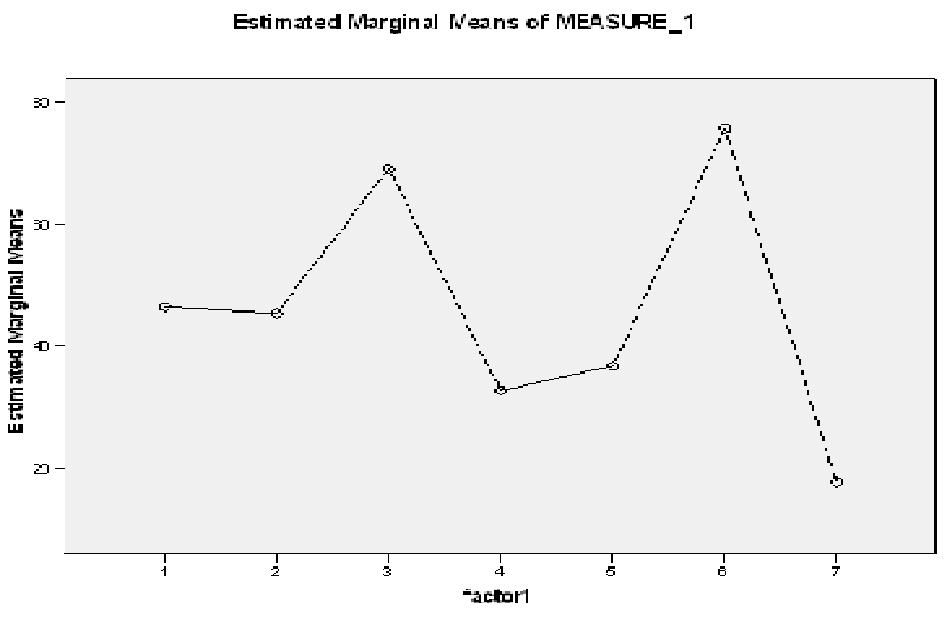

Figure 4.1 Histogram of VLS in Advanced level
1. Metacognitive regulation
2. Guessing strategies
3. Dictionary strategies
4. Note-taking strategies

5. Memory strategies: rehearsal

6.Memory strategies: encoding

7. Activation strategies

\subsection{Descriptive Statistics of VLS in the Intermediate Level}

The descriptive statistics of VLS in the intermediate participants is presented in table 4.4.

Table 4.4 Descriptive statistics of VLS in intermediate level

\begin{tabular}{lccccc}
\hline & N & Minimum & Maximum & Mean & $\begin{array}{c}\text { Std. } \\
\text { Deviation }\end{array}$ \\
\hline $\begin{array}{l}\text { Metacognitive } \\
\text { Regulation }\end{array}$ & 95 & 20.00 & 49.00 & 35.7263 & 7.51798 \\
\hline Guessing Strategies & 95 & 18.00 & 53.00 & 32.1789 & 9.88119 \\
\hline Dictionary Strategies & 95 & 37.00 & 71.00 & 53.3895 & 8.20391 \\
\hline Note.-Taking Strategies & 95 & 14.00 & 40.00 & 26.0316 & 6.07831 \\
\hline $\begin{array}{l}\text { Memory-strategies: } \\
\text { Rehearsal }\end{array}$ & 95 & 21.00 & 44.00 & 31.3684 & 6.53640 \\
\hline $\begin{array}{l}\text { Memory-strategies: } \\
\text { encoding }\end{array}$ & 95 & 29.00 & 86.00 & 54.8842 & 19.59747 \\
\hline Activation Strategies & 95 & 5.00 & 20.00 & 13.3474 & 4.82407 \\
\hline Valid N (listwise) & 95 & & & & \\
\hline
\end{tabular}


The above table shows, as in the advanced level, Memory Strategies: encoding is the highest used strategies in the intermediate learners with the mean of54.88. Dictionary Strategies enjoy the second rank in this group with the mean of 53.38; in addition, the least used strategies are Activation Strategies with the mean of 13.37. Figure 4.2 shows the related histogram of VLS in intermediate group.

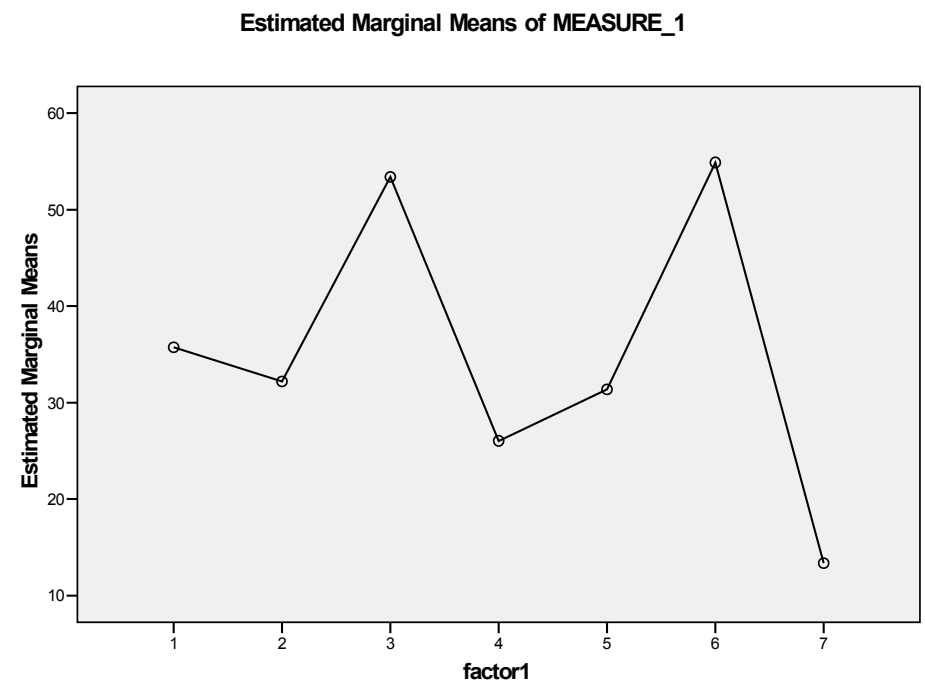

Figure 4.2 Histogram of VLS in intermediate group

1.Metacognitive regulation

2.Guessing strategies

3.Dictionary strategies

4.Note-taking strategies
5.Memory strategies: rehearsal 6.Memory strategies: encoding 7.Activation strategies

\subsection{Testing the Null Hypothesis}

The current study examined the relationship between learner autonomy and vocabulary learning strategies in advanced/intermediate Iranian EFL learners. In this section, the researcher mentioned responses from data analysis and presented in a way that address the four null hypotheses posed in this study.

\subsubsection{Testing the First Null Hypothesis}

To test the first null hypothesis, the researcher utilized the non-parametric Spearman rank order correlation to estimate the magnitude of the relationship between the two variables. The following table shows the result:

Table 4.5 Correlations between learner autonomy and VLS in advanced learners

\begin{tabular}{|c|c|c|c|c|}
\hline & & & $\begin{array}{l}\text { Learner } \\
\text { Autonomy in } \\
\text { Advanced } \\
\text { Group }\end{array}$ & $\begin{array}{l}\text { Vocabulary } \\
\text { Leaning } \\
\text { Strategies in } \\
\text { Advanced } \\
\text { Group }\end{array}$ \\
\hline \multirow[t]{6}{*}{ Spearman's rho } & \multirow[t]{3}{*}{$\begin{array}{l}\text { autonomy advanced } \\
\text { group }\end{array}$} & $\begin{array}{l}\text { Correlation } \\
\text { Coefficient }\end{array}$ & 1.000 & $.457^{* *}$ \\
\hline & & Sig. (2-tailed) & . & .000 \\
\hline & & $\mathrm{N}$ & 95 & 95 \\
\hline & \multirow{3}{*}{$\begin{array}{l}\text { vocabulary leaning } \\
\text { strategies, advanced } \\
\text { group }\end{array}$} & $\begin{array}{l}\text { Correlation } \\
\text { Coefficient }\end{array}$ & $.457^{* *}$ & 1.000 \\
\hline & & Sig. (2-tailed) & .000 & . \\
\hline & & $\mathrm{N}$ & 95 & 95 \\
\hline
\end{tabular}

**. Correlation is significant at the 0.01 level (2-tailed).

As shown above the correlation turned out to be significant $(\mathrm{Rho}=.457, \mathrm{p}=.000<.05)$. However, the coefficient is moderate in size. 
As the Table 4.5 depicts, there is a statistically positive correlation between participants' learner autonomy and their vocabulary strategies in the advanced levels. Aoki (2008) states that the strategies learners use in self-instruction context and the degree of autonomy they exercise would help them develop foreign language skills without the help of a teacher or language group(s). Consequently, one can conclude that students with high level of proficiency self-instruct themselves and apply self-regulative strategies which help them develop learning skills autonomously and independently.

Scharle and Szabo (2000) express learning strategies as one of the most important building blocks of responsibility and autonomy. It seems that students need to gain the awareness of the determining role of language learning strategies and learning autonomy as contributing factors to their success in the process of learning a target language. Moreover, responsible learners (Scharle \& Szabo, 2000) are those who accept the idea that their own efforts are crucial to progress in learning and behave accordingly. These notions are in line with the results obtained from students in high proficient group.

\subsubsection{Testing the Second Null hypothesis}

To check whether learner autonomy in advanced learners can significantly predict their VLS, a linear regression analysis was conducted. The following tables show the output thereof.

Table 4.6 Model Summary ${ }^{\mathrm{b}}$

\begin{tabular}{llcccc}
\hline Model & $\mathrm{R}$ & R Square & $\begin{array}{c}\text { Adjusted R } \\
\text { Square }\end{array}$ & $\begin{array}{c}\text { Std. Error of the } \\
\text { Estimate }\end{array}$ & $\begin{array}{c}\text { Durbin- } \\
\text { Watson }\end{array}$ \\
\hline 1 & $.430^{\mathrm{a}}$ & .185 & .176 & 43.58701 & 2.025 \\
\hline a. Predictors: (Constant), autonomy advanced group \\
b. Dependent Variable: vocabulary leaning strategies, advanced group
\end{tabular}

As demonstrated by the above table, $\mathrm{R}$ came out to be .43 (the correlation coefficient between the two variables) and the $\mathrm{R}$ square turned out to be .185 . The following table reports the result of ANOVA.

\begin{tabular}{lrrrrrr} 
Table $^{2}$ 4.7 ANOVA $^{\mathrm{b}}$ & & & & & \\
\hline Model & Sum of Squares & df & Mean Square & F & Sig. \\
\hline 1 & Regression & 40139.560 & 1 & 40139.560 & 21.128 & $.000^{\mathrm{a}}$ \\
& Residual & 176683.977 & 93 & 1899.828 & & \\
Total & 216823.537 & 94 & & & \\
\end{tabular}

a. Predictors: (Constant), autonomy advanced group

b. Dependent Variable: vocabulary leaning strategies, advanced group

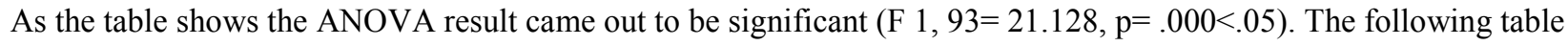
displays the regression output:

Table 4.8 Coefficients ${ }^{\mathrm{a}}$

\begin{tabular}{|c|c|c|c|c|c|}
\hline \multirow[b]{2}{*}{ Model } & \multicolumn{2}{|c|}{ Unstandardized Coefficients } & $\begin{array}{l}\text { Standardized } \\
\text { Coefficients }\end{array}$ & \multirow[b]{2}{*}{$\mathrm{t}$} & \multirow[b]{2}{*}{ Sig. } \\
\hline & $\mathrm{B}$ & Std. Error & Beta & & \\
\hline 1(Constant) & 131.233 & 42.294 & & 3.103 & .003 \\
\hline autonomy advanced group & 2.472 & .538 & .430 & 4.597 & .000 \\
\hline
\end{tabular}

a. Dependent Variable: vocabulary leaning strategies, advanced group

The output is significant as the sig is .003 that is less than .05. It means that autonomy can significantly predict the VLS in advanced learners.

\subsubsection{Testing the Third Hypothesis}

To test the third hypothesis, that is, the relationship between learner autonomy and vocabulary learning strategies in intermediate Iranian EFL learners the researcher used Pearson Product correlation between the two variables of learner autonomy and VLS in the intermediate level EFL students. The following table shows the result: 
Table4 .9 Correlation between learner autonomy and VLS in intermediate students

\begin{tabular}{llcc}
\hline & Pearson Correlation & $\begin{array}{c}\text { Learner } \\
\text { Autonomy, } \\
\text { intermediate } \\
\text { group }\end{array}$ & $\begin{array}{c}\text { vocabulary } \\
\text { learning } \\
\text { strategies, } \\
\text { Intermediate }\end{array}$ \\
\hline $\begin{array}{l}\text { Learner Autonomy, } \\
\text { intermediate group }\end{array}$ & Sig. (2-tailed) & 1 & $.249^{*}$ \\
& $\mathrm{~N}$ & 95 & .015 \\
vocabulary learning & Pearson Correlation & $.249^{*}$ & 95 \\
strategies, Intermediate & Sig. (2-tailed) & .015 & 1 \\
& $\mathrm{~N}$ & 95 & 95 \\
\hline
\end{tabular}

*. Correlation is significant at the 0.05 level (2-tailed).

As the table shows the correlation turned to be significant $(r=.249, \mathrm{p}=.015<.05)$. However, the magnitude of the correlation is medium.

The results indicate a positive correlation between these two constructs. The correlation came to be significant, the magnitude of the correlation was not very remarkable though (as shown in Table 4.9, $\mathrm{r}=.249$ ). Based on the results, one can conclude that no student is thoroughly without a sense of autonomy and vocabulary learning strategies use. This statement is consistent with Scharle and Szabo's (2000) notion that no student is completely without a sense of responsibility and we are not to face with an ideal responsible student, either. Preferred learning style, cultural attitudes, and personality traits set limit to the development of autonomy. Thus, it is in line with the fact that students in intermediate level might be unaware of the determining roles of autonomy and vocabulary learning strategies in the process of moving towards language proficiency.

\subsubsection{Testing the Fourth Hypothesis}

In order to see whether learner autonomy can significantly predict VLS in intermediate learners, a regression was conducted. The following tables how the result:

Table 4.10 Model Summary

\begin{tabular}{lrrrr}
\hline Model & R & R Square & $\begin{array}{c}\text { Adjusted R } \\
\text { Square }\end{array}$ & $\begin{array}{c}\text { Std. Error of the } \\
\text { Estimate }\end{array}$ \\
\hline 1 & $.249^{\mathrm{a}}$ & .062 & .052 & 48.68066 \\
\hline
\end{tabular}

a. Predictors: (Constant), Learner Autonomy, intermediate group

As demonstrated by the above table, $\mathrm{R}$ came out to be .249 (the correlation coefficient between the two variables) and the R square turned out to be .062 . The following table reports the result of ANOVA.

Table 4.11 ANOVA $^{\mathrm{b}}$

\begin{tabular}{llrrrr}
\hline Model & $\begin{array}{l}\text { Sum of } \\
\text { Squares }\end{array}$ & df & Mean Square & F & Sig. \\
\hline 1Regression & 14576.487 & 1 & 14576.487 & 6.151 & $.015^{\mathrm{a}}$ \\
Residual & 220391.998 & 93 & 2369.806 & & \\
Total & 234968.484 & 94 & & & \\
\hline
\end{tabular}

a. Predictors: (Constant), Learner Autonomy, intermediate group

b. Dependent Variable: vocabulary learning strategies, Intermediate

As the table shows the ANOVA result came out to be significant $(\mathrm{F} 1,93=6.151, \mathrm{p}=.015<.05)$. The following table displays the regression output: 


\begin{tabular}{|c|c|c|c|c|c|c|}
\hline \multirow[b]{2}{*}{ Model } & & \multicolumn{2}{|c|}{ Unstandardized Coefficients } & \multirow{2}{*}{$\begin{array}{c}\begin{array}{c}\text { Standardized } \\
\text { Coefficients }\end{array} \\
\text { Beta }\end{array}$} & \multirow[b]{2}{*}{$\mathrm{t}$} & \multirow[b]{2}{*}{ Sig. } \\
\hline & & $\mathrm{B}$ & Std. Error & & & \\
\hline 1 & (Constant) & 174.326 & 29.696 & & 5.870 & .000 \\
\hline & $\begin{array}{l}\text { Learner Autonomy, } \\
\text { intermediate group }\end{array}$ & 1.187 & .479 & .249 & 2.480 & .015 \\
\hline
\end{tabular}

a. Dependent Variable: vocabulary learning strategies, Intermediate

The above table shows that the standardized Beta coefficient turned out to be significant $(\mathrm{B}=.249, \mathrm{t}=2.48, \mathrm{p}=.015<$ .05) meaning that learner autonomy can significantly predict VLS in intermediate learners.

At the end, it is important to stress that any conclusion should be interpreted in the light of the many limitations and delimitations that the researcher had in conducting the research. Also, no significant relationship may be found in some parts which might be attributed partly to the nature of the instruments used for data collection. A difficulty with the use of questionnaires is the fact that some participants might have not reported what they actually do due to either personal or educational reasons (Hatch \& Farhadi, 1982).

\section{Conclusion}

The researcher in this study tried to investigate the relationship between learner autonomy and vocabulary learning strategies in Iranian EFL learners with different language proficiency level.

Based on the data analysis, the researcher found that there was a significant relationship between learner autonomy and vocabulary learning strategies in Iranian advanced EFL learners. With a positive correlation of $r=.457$ we can say that for high proficient EFL learners vocabulary learning strategies were found to be significantly related to learner autonomy. Therefore, the first null hypothesis, i.e. there is no relationship between learner autonomy and vocabulary learning strategies in Iranian advanced EFL learners, was rejected. Using the pertinent statistics procedure, it was shown that learner autonomy significantly predicts vocabulary learning strategies in Iranian advanced EFL learners, so the second null hypothesis of this study was rejected.

On the other hand, with a rather positive between these two variables in the intermediate group, i.e. $r=.249$, the third null hypothesis was rejected. Processed data show that learner autonomy significantly predicts vocabulary learning strategies in the intermediate level; accordingly the fourth null hypothesis is also rejected.

Taking this fact into account that the relationship between these two variables in intermediate level was not as significant as in the advanced group, we can come to conclusion that the higher the level of learner autonomy, the higher of vocabulary leaning strategies use will be.

Learners who are highly autonomous have tools to make the learning easier and more manageable as well as solution to overcome problems associated with learning. They monitor their own learning and have learned how to deal with anxiety, nervousness, and fear of making mistakes.

\subsection{Pedagogical Implications}

Traditionally, the majority of teachers and learners tended to think the learner's responsibility should be limited to being beneficiary of the process, its active manager being the teacher. However, in recent years with the appearance of learner-cantered- approaches and self-directed learning, learners should have the choice between taking the full responsibility for the process or simply submitting to it. They should be free to decide whether want to self-direct or let others direct it for them. However, to exercise this responsibility, learners must be in a position to do so (Littlewood, 1999).

The relationship might be beneficial to students, teachers, and material developers. For instance, teachers can focus on strategy-based instruction for more effective learning and also find faster and less time-consuming ways to teach based on learners' autonomy levels. In addition, learners could be directed to the best and most suitable ways of learning and also they can be life-long autonomous learners. Language learning is a lifelong effort. It is important to help learners become aware of the value of independent learning outside the classroom so that they can learn continuously, and maintain it after they have completed their formal studies. Learning to be self-directed involves taking responsibility for the objectives of learning, self-assessing, and taking an active role in learning. The value of the learner autonomy is at times discussed in terms of a constructive association between present and future learning. Learners who admit responsibility for their learning are more probable to attain their learning goals; and if they achieve their learning targets, they are more likely to keep an optimistic attitude to learning in the future.

Vocabulary learning is extremely critical to English language acquisition. It is impracticable for a learner to communicate without the required lexis. No doubt that a learner cannot gain knowledge of all language vocabulary in classes; consequently he is obliged to uncover other ways to learn vocabulary. Once learners happen to autonomous in vocabulary learning, they have acquired a enduring learning skill and a habit of independent thinking and learning which will benefit them long after leaving the formal setting of education.

Finally, from the correlation in advanced level, one can conclude that second and foreign language learners who have high level of autonomy and vocabulary learning strategies achieve high levels of language proficiency in the target language. 


\section{References}

Aoki, N. (2008). Teacher stories to improve theories of learner/teacher autonomy. Independence, 43, 15-17.

Bocanegra, A., \& Haidi, A. W. (1999). Language learner autonomy in practice: possibilities in a foreign language situation. Revista Alicantina de Estudios Ingleses, 12, 7-17.

Carter, R. (1989). Vocabulary acquisition. Aila Review-Revue de L'aila, 6, 5-9.

Chamot, A. U. (2004). Issues in Language Learning Strategy Research and Teaching. Electronic Journal of Foreign Language Teaching, 1(1), 14-26.

Cotterall, S. (2000). Promoting learner autonomy through the curriculum: principles for designing language courses. English Language Teaching Journal, 54(2), 109-117.

Dafei, D. (2007). An exploration of the relationship between learner autonomy and English proficiency. Professional Teaching Article, 1-23.

Gremmo, M. -J., \& Riley, P. (1995). Autonomy, self-direction and self-access in language teaching and learning: The history of an idea. System, 23(2), 151-164.

Gu, Y., \& Johnson. R. K. (1996). Vocabulary language learning and language learning outcome. Language Learning, 46(4). 643-679.

Haghi, M. (2009). The relationship between perceived self-efficacy and Iranan learners. Unpublished MA thesis, Islamic Azad University, Science and Research Branch. Tehran. Iran.

Hatch, E., \& Farhadi, H. (1982). Research design and statistics for applied linguistics. Massachusset: Newbury House.

Hedge, T. (2000). Teaching and learning in the language classroom. Oxford, Oxford University Press.

Little, D. (1995). Learning as dialogue: The dependence of learner autonomy on teacher autonomy. System, 23(2), 175181 .

Little, D. (2007). Language learner autonomy: some fundamental considerations revisited. Innovation in Language Learning and Teaching, 1(1), 14-29. doi: 10.2167/illt040.0.

Littlewood, W. (1996). "Autonomy”: An anatomy and a framework. System, 24(4), 427-435.

Littlewood, W. (1999). Defining and developing autonomy in East Asian contexts. Applied Linguistics, 20(1), 71-94.

Mackey, A., \& Gass, S. M. (2005). Second language research: Methodology and Design. New Jersey, Lawrence Erlbaum Associates.

Nation, I. S. P. (2001). Learning Vocabulary in another Language. Cambridge, Cambridge University Press.

Oxford, R. (1994). Language learning strategies: an update. CAL, Center for Applied Linguistic, 1-8.

Oxford, R. (2003). Language learning styles and strategies: an overview. GAlA, 1-25.

Scharle, A. \& Szabo, A. (2000). Learner autonomy: A guide to developing learner responsibility. Cambridge: Cambridge University Press.

Tahmasebi, A. (1999). Vocabulary learning strategies and the level of language proficiency. Unpublished MA thesis, Tarbiat Modarres University. Tehran, Iran. 